\title{
1 Vent-Lock: A 3D Printed Ventilator Multiplexer to Enhance the Capacity of Treating
} 2 Patients with COVID-19

3

4

5

4

7

. Vladimirov $^{3}$, Jenna Frye ${ }^{4}$, Mohit Singhala ${ }^{5}$, Brockett Horne ${ }^{4}$, Pooja Yesantharao ${ }^{1}$, Bo Soo Kim ${ }^{1}$, Broc Burke ${ }^{6}$, Michael Montana ${ }^{6}$, Michael Talcott ${ }^{6}$, Bradford Winters ${ }^{1}$, Margaret Frisella ${ }^{6}$, Bradley Kushner ${ }^{6}$, Justin M. Sacks ${ }^{6}$, James K. Guest ${ }^{3}, *$, Sung Hoon Kang ${ }^{5}$, , Julie Caffrey ${ }^{1, *}$

${ }^{1}$ Johns Hopkins School of Medicine, Baltimore, MD, 21231

${ }^{2}$ Department of Biomedical Engineering, Johns Hopkins University, Baltimore, MD, 21231

${ }^{3}$ Department of Civil and Systems Engineering, Johns Hopkins University, Baltimore, MD, 21218

${ }^{4}$ Maryland Institute College of Art, Baltimore, MD, 21217

${ }^{5}$ Department of Mechanical Engineering, Johns Hopkins University, Baltimore, MD, 21218

${ }^{6}$ Washington University in St. Louis School of Medicine, St. Louis, Missouri, 63130

*To whom correspondence should be addressed: jkguest@jhu.edu, shkang@jhu.edu, jcaffre5@jhmi.edu

(n)


33 ABSTRACT: Mechanical ventilators are essential to patients who become critically ill from

34 acute respiratory distress syndrome (ARDS), and shortages have been reported due to the novel

35 severe acute respiratory syndrome coronavirus 2 (SARS-CoV-2). We utilized cost-effective, on-

36 demand 3D printing (3DP) technology to produce critical components for a novel ventilator

37 multiplexer system, Vent-Lock, to split one ventilator or anesthesia gas machine between two

38 patients. FloRest, a novel 3DP flow restrictor, provides clinicians control of tidal volumes and

39 positive end expiratory pressure (PEEP), using the 3DP manometer adaptor to monitor pressures.

40 We tested the ventilator splitter circuit in simulation centers between artificial lungs and used an

41 anesthesia gas machine to successfully ventilate two swines. As one of the first studies to

42 demonstrate splitting one anesthesia gas machine between two swines, we present proof-of-

43 concept of a de novo, closed, multiplexing system, with flow restriction for individualized patient

44 therapy. Our studies underscore that while possible, ventilator multiplexing is a complicated

45 synergy between machine settings, circuit modification, and patient monitoring. Consequently,

46 ventilator multiplexing is reserved only as a last emergency resource, by trained clinicians and

47 respiratory therapists with ventilator operative experience. 
medRxiv preprint doi: https://doi.org/10.1101/2020.09.16.20195230; this version posted September 22, 2020. The copyright holder for this

It is made available under a CC-BY-NC-ND 4.0 International license .

\section{INTRODUCTION}

55 The novel severe acute respiratory syndrome coronavirus 2 (SARS-CoV-2) has led to a

56 global pandemic resulting in rapid depletion of resources necessary to care for critically ill

57 patients, such as mechanical ventilators and their associated parts. Mechanical ventilators are

58 critical for the treatment of approximately 5-10\% of patients with coronavirus disease (COVID-

59 19) who become critically ill from acute respiratory distress syndrome (ARDS) ${ }^{1}$. In the face of

60 the COVID-19 pandemic, it is estimated that there is a global ventilator shortage of $880,000^{2}$.

61 This shortage may disproportionately affect developing countries who suffer from lack of

62 medical infrastructure and resources ${ }^{3}$, historically resulting in higher mortality rates in

63 pandemics such as the Spanish Flu ${ }^{4}$. For example, the continent of Africa has limited ventilator

64 capacity, with only 2,000 ventilators across 41 countries ${ }^{5}$. This capacity deficit is further

65 worsened by the increased need due to the COVID-19 pandemic.

Ventilator shortages occur in resource-rich countries as well. Previous disasters and

67 current projections suggest that hospitals may be operating at $120-160 \%$ capacity in the face of a

68 pandemic or national disaster ${ }^{6}$. Projections suggest that if $20 \%$ of the United States population is

69 infected with the virus, there will be significant deficiencies in intensive care unit beds and

70 mechanical ventilators ${ }^{6,7}$. Furthermore, given the potential for a second wave of infection,

71 epidemiologists predict that if countries continue to lift restrictions used to slow the spread of the

72 virus too early, then a second global peak may result in a further shortage of medical supplies ${ }^{8}$,

73 ventilators and ventilator associated parts. The Society of Critical Care Medicine shared that

74 clinicians continue to report ventilator shortages in summer of 2020, including $53 \%$ of 587

75 surveyed ICU clinicians did not have enough ventilators and had to use non-standard ventilators

76 or non-invasive devices, and a small percentage declined care due to shortage of ventilators, or 
It is made available under a CC-BY-NC-ND 4.0 International license .

77 placed two patients on one ventilator ${ }^{9}$. Consequently, there is a critical need to address urgent

78 ventilator shortages in the face of the COVID-19 pandemic.

While the introduction of more ventilators, either de novo or commercial, could solve the

80 urgent medical needs arising from the COVID-19 pandemic, this solution represents a theoretical

81 ideal that cannot be achieved given the current monetary, time, hospital infrastructure, limited

82 scaling and production capacity, and supply chain constraints ${ }^{10,11}$, further exacerbated by lack

83 of standardization of parts across brands ${ }^{12}$. An alternative strategy to quickly increase ventilator

84 capacity as an immediate step in urgent settings is to "split" or multiplex ventilators and

85 anesthesia gas machines. Ventilator multiplexing allows the usage of one machine to ventilate

86 multiple patients and effectively increases the clinical capacity to support urgent needs.

87 The concept of using one ventilator to support multiple patients during a disaster surge

88 was first published in 2006 by Neyman et al. ${ }^{13}$, who reported that four patients could be

89 supported for 12 hours using ventilator equipment and tubing. However, these in vitro studies

90 were restricted to patients with similar body habitus and lung compliances. Despite these study

91 limitations, it introduced ventilator multiplexing as a potential solution for emergency situations.

92 In 2017, this proof-of-concept was demonstrated in actual patients during the 2017 Las Vegas

93 shooting ${ }^{14}$ when a physician supported multiple patients on a single ventilator as a temporary

94 emergency situation until more resources became available. The ability to multiplex ventilators

95 is valuable for global preparedness mechanisms to promptly increase ventilator capacity as an

96 immediate response for disasters, such as trauma surges, natural disasters, or in military

97 frontlines.

98 Emergency use of ventilator multiplexing is dependent on the dynamic lung states of the

99 patients, including associated lung compliances and airway resistances that drive airflow 
100 balance. In the evolving pathologic state of COVID-19 patients with ARDS, an interdependent

101 ventilation system poses many safety concerns. The Society of Critical Care Medicine and other

102 societies in respiratory care issued a joint statement ${ }^{15}$ summarizing main concerns with

103 ventilator multiplexing ${ }^{16}$, including the inability to independently monitor and control

104 ventilation parameters (volumes, pressures, rates) critical for ARDS treatment, thus risking

105 adverse outcomes such as underventilation, or ventilator induced lung injury (VILI) such as

106 barotrauma. Additional concerns include ventilator alarm management, disrupted balance of

107 ventilation if a patient has spontaneous breathing, sudden deterioration, kink in the tubing, and

108 viral contamination if breathing circuits between patients are mixed, or the circuit becomes open.

109 While these barriers exist, they are not insurmountable for emergency ventilator

110 multiplexing. For example, recent engineering solutions have emerged using off-the-shelf

111 medical components that mitigate concerns in ventilator multiplexing by volume or pressure

112 control, and monitoring ${ }^{17}$. It is optimistic that these circuits present potential solutions for

113 ventilator shortages in emergency situations; however, deployment can be limited due to

114 unstable supply chains that make these off-the-shelf medical components difficult to acquire ${ }^{18}$,

115 even in developed countries up to six months from inciting events ${ }^{19}$. Consequently, rapid

116 production of de novo ventilator multiplexing solutions are investigated to further address these

117 barriers.

118 Among multiple modalities for de novo manufacturing to address medical equipment

119 shortages, 3D printing has come to the forefront during the COVID-19 pandemic to address

120 critical shortages ${ }^{12,20} .3 \mathrm{D}$ printing is a type of additive manufacturing that has emerged in the

121 past decades as a cost-effective, rapid on-demand production modality with broad applications

122 due to its ability to produce intricate and complex geometries from computer-aided designs 
123 without tooling and expensive machines ${ }^{21} .3 \mathrm{D}$ printing enables faster design and manufacturing

124 processes $^{22}$, so that it can be utilized in emergency situations to fill gaps in the supply chain ${ }^{23}$.

125 Specifically, in reference to COVID-19, there have been multiple shortages in ventilator

126 associated equipment and valves, leading healthcare providers to look into different avenues of

127 manufacturing to address the gap in the supply ${ }^{20}$. Ventilator splitter products which primarily

128 use commercial medical equipment may have limited or unreliable supply ${ }^{17}$ in urgent situations.

129 We address urgent medical needs arising from unstable supply chains by using 3D printing to

130 rapidly and cost-effectively prototype and test components of our ventilator splitter circuit using

131 biocompatible and sterilizable materials.

132 In this study, we present Vent-Lock, a de novo, ventilator multiplexing system that

133 addresses major concerns with ventilator splitting, and is rapidly produced via 3D printing, thus

134 tapping into a broad international production infrastructure largely unaffected by the pandemic.

135 The Vent-Lock breathing circuit provides clinicians with a way to control, manage and monitor

136 patients split on one ventilator; circuit components allow for the change in individual tidal

137 volumes and positive end expiratory pressure (PEEP), pressure monitoring, and minimized back

138 flow and risk of contamination. Our novel, air-tight, 3DP flow restrictor (FloRest) is designed to

139 provide clinicians with precise control of tidal volumes. We validate the use of Vent-Lock

140 FloRest for both ventilators and anesthesia gas machines, successfully ventilating simulated

141 patients with mismatched lung compliances. Furthermore, we ventilated two swine safely with

142 Vent-Lock, demonstrating the device's ability to both safely multiplex patients and to evolve

143 anesthesia gas machines (which are more commonly available in developing countries as

144 compared to ventilators) with increased ventilation settings. We share differences in multiplexing

145 of anesthesia gas machines and ventilators, and the impact of ventilator control mode (volume 
medRxiv preprint doi: https://doi.org/10.1101/2020.09.16.20195230; this version posted September 22, 2020. The copyright holder for this

It is made available under a CC-BY-NC-ND 4.0 International license .

146 control versus pressure control) on multiplexing, and additional challenges. The novel, de novo,

147 3DP Vent-Lock circuit and FloRest is well positioned to rapidly increase capacity of mechanical

148 ventilators to provisionally meet ventilator shortages due to the COVID-19 pandemic and future

149 pandemics and disasters.

\section{$151 \quad$ RESULTS}

152 Vent-Lock $1+n(1)$ circuit and components

We validated a $1+n(1)$ system which can split one ventilator between one standard patient

154 and one or potentially more variable patients (Fig.1). The standard patient ideally has the lowest

155 lung compliance and has minimal components in the circuit to establish low resistance allowing

156 the ventilator to maintain standard function. The standard patient will be ventilated at pressure

157 settings unaltered from that delivered by the ventilator. Additional patients (n) added to the

158 circuit are considered variable patients and can have their tidal volumes and PEEP altered by

159 circuit components. This paper demonstrates use of a ventilator splitter adjusting for 1 control

160 and $n=1$ variable patients. The $1+n(1)$ split contains Vent-Lock 3DP parts and commercial parts

161 (Fig. 1). We 3D printed the splitters and the flow restrictors (needle valves). The other parts

162 including the one-way check valves, the filters and the PEEP valves were all commercial parts

163 (fig. S1). The Vent-Lock circuit was designed to be closed circuit and leak-free to minimize risk

164 of aerosolizing viral particles into the surrounding environment.

166 Vent-Lock 3DP Flow Restrictor (FloRest)

167 The Vent-Lock 3DP flow restrictor (Vent-Lock FloRest) is a flow restrictor based on a

168 needle control valve design optimized for low flow rates to offer clinicians robust control over a 
medRxiv preprint doi: https://doi.org/10.1101/2020.09.16.20195230; this version posted September 22, 2020. The copyright holder for this preprint (which was not certified by peer review) is the author/funder, who has granted medRxiv a license to display the preprint in perpetuity.

It is made available under a CC-BY-NC-ND 4.0 International license .

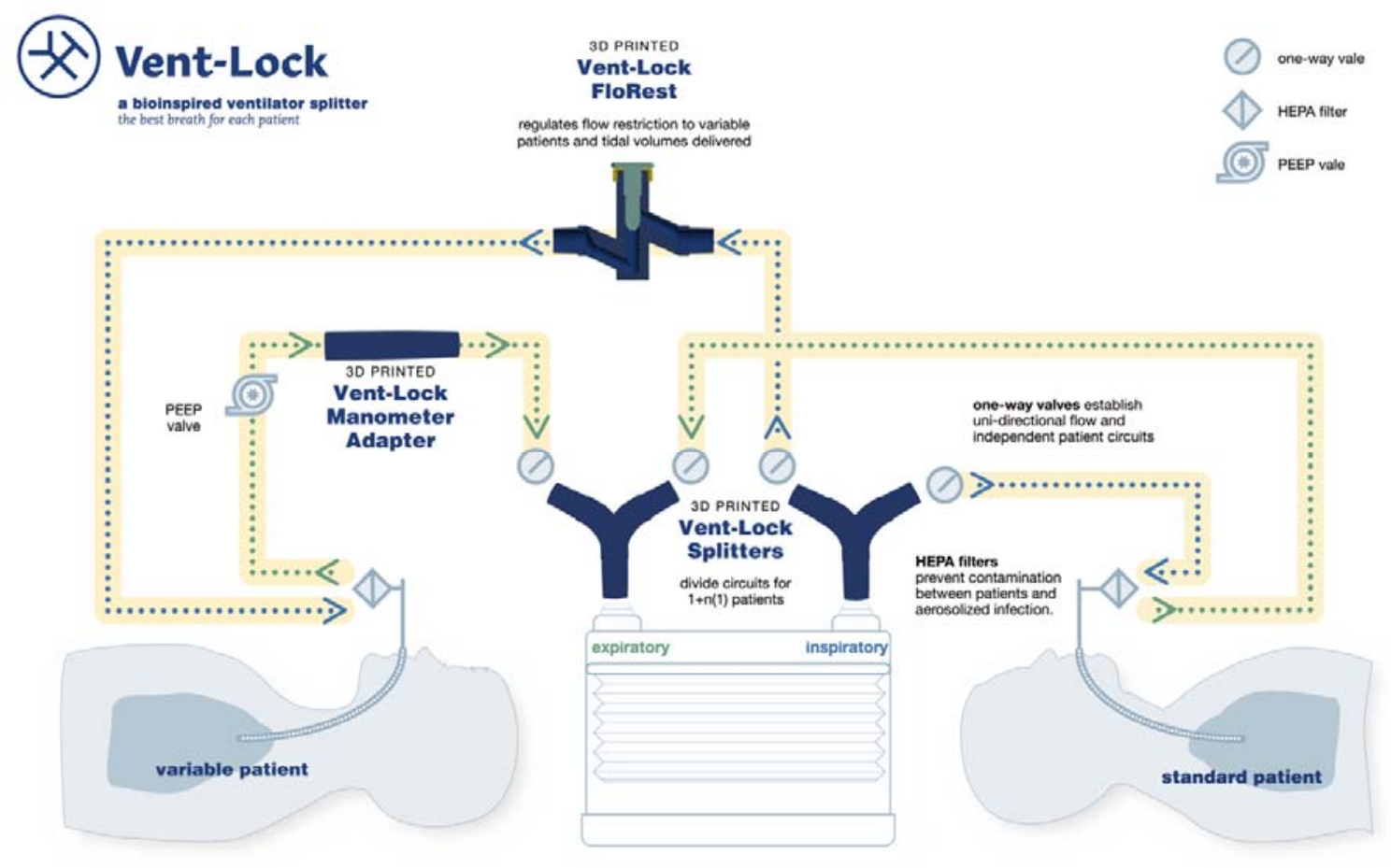

172 Fig. 1. Vent-Lock ventilator multiplexing 1+n(1) circuit and 3DP components. Our 1+n(1) circuit proposes

173 having a standard patient with minimal features, thus are ventilated per ventilator settings. Additional patients added

174 to the circuit will be considered n(1), and will have variable flow and PEEP as controlled by circuit components.

175 Please note that all patients, regardless of standard or variable, have one-way (check) valves and filters.

177 between patients, 2. PEEP would be difficult to manage per patient, 3. Tidal volumes would be

178 difficult to manage per patient and 4. Adjustment or discontinuation of ventilation to one patient 179 would alter breathing dynamics to other patients.

180 The goal of FloRest (Fig. 2A) was to allow the clinician to modify the flow rate of air 181 being delivered to the patient, thus providing ranges of clinical tidal volumes and PEEPs with 182 control sensitivity and a reliable linear relationship between closure and flow rate, tidal volume, 
medRxiv preprint doi: https://doi.org/10.1101/2020.09.16.20195230; this version posted September 22, 2020. The copyright holder for this preprint (which was not certified by peer review) is the author/funder, who has granted medRxiv a license to display the preprint in perpetuity.

It is made available under a CC-BY-NC-ND 4.0 International license .

183 and pressures. The design emphasizes the minimization of build time and volume by reducing

184 support material use and complex structures for consistent and higher quality printing. These

185

186

(A)
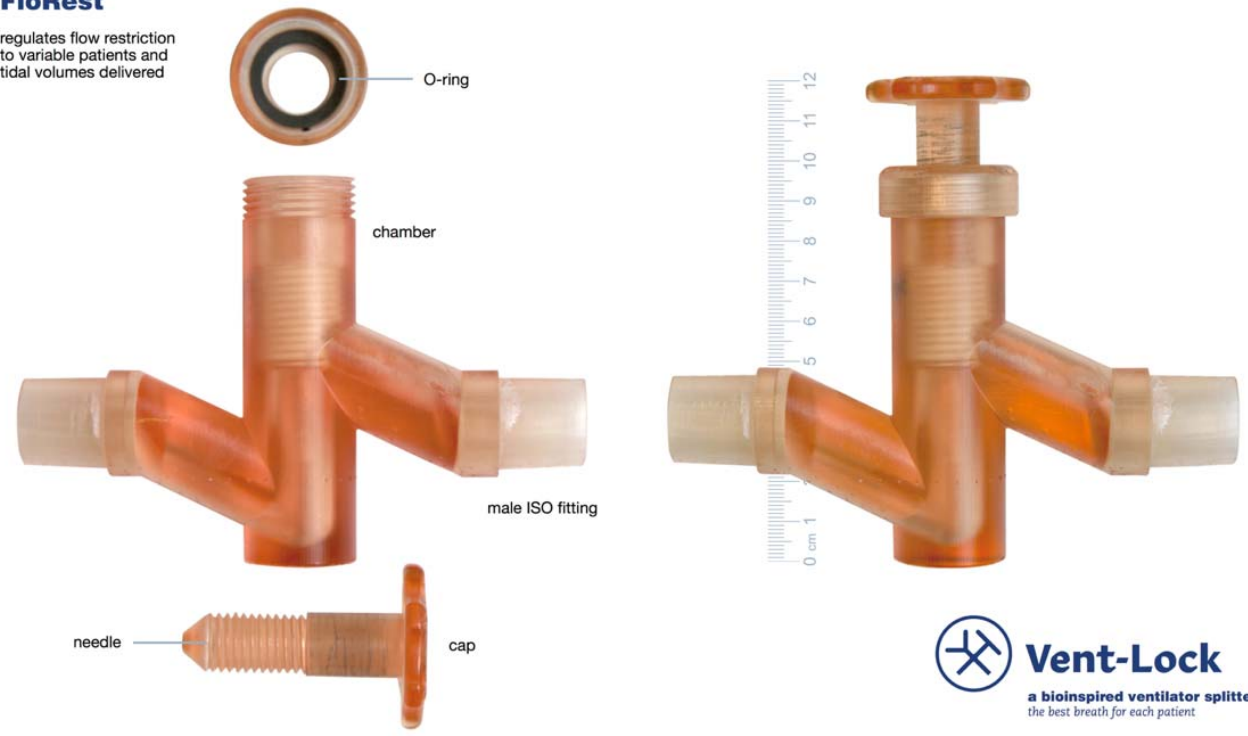

196

(B)

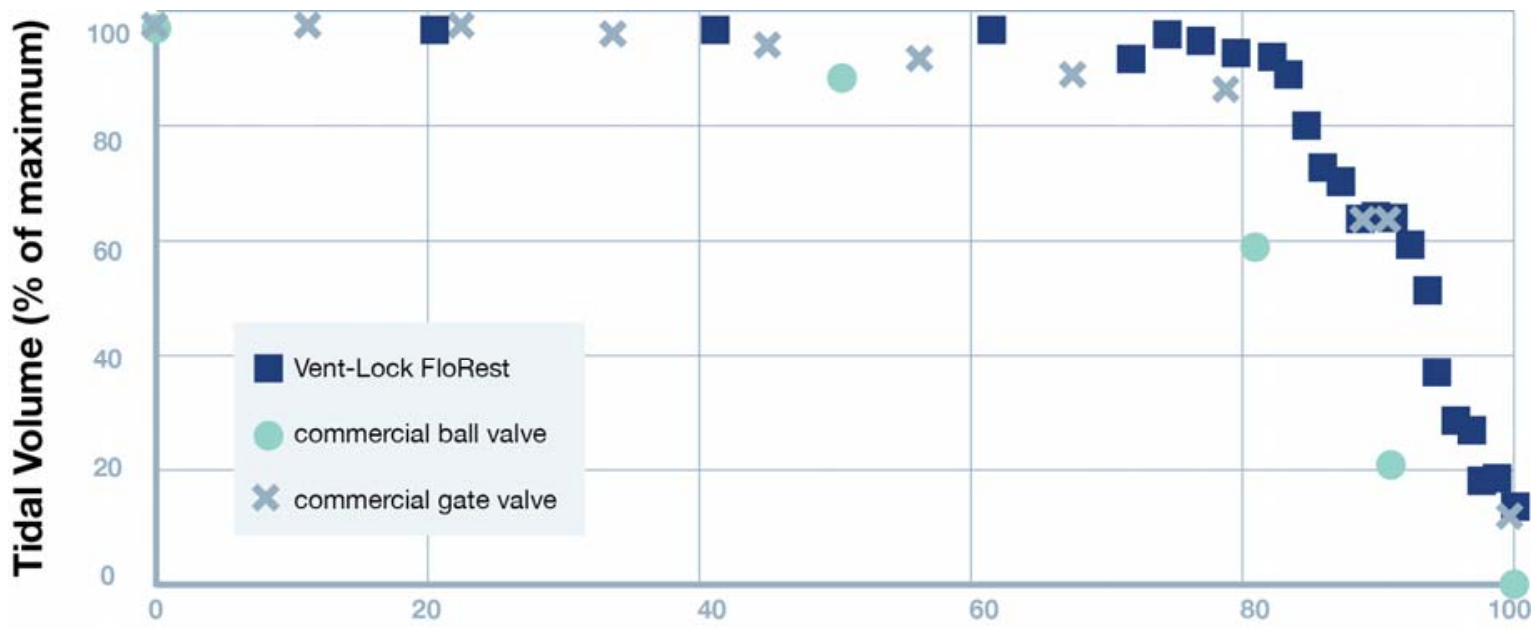

\section{Vent-Lock FloRest Closure (\%)}

197 Figure 2. Design and performance of 3DP Flow Restrictor (FloRest). (A) Vent-Lock 3DP Flow Restrictor

198 (FloRest) contains three components. The O-ring between the cap and full-height threaded needle interface at the top

199 of the chamber to maintain air-tight seals. Both ends of Vent-Lock FloRest are male ISO fittings to ensure 
medRxiv preprint doi: https://doi.org/10.1101/2020.09.16.20195230; this version posted September 22, 2020. The copyright holder for this preprint (which was not certified by peer review) is the author/funder, who has granted medRxiv a license to display the preprint in perpetuity.

It is made available under a CC-BY-NC-ND 4.0 International license .

connection to ventilator tubing. (B) Testing with a ventilator on pressure control using simulation lungs at varying compliances demonstrates that Vent-Lock FloRest provides more control options than commercial ball valves and gate valves, characterized by more available data points corresponding with different tidal volumes delivered.

considerations allowed for an air-tight and leak-proof design (fig. S2) and utilization of biocompatible materials that can withstand extended exposure to warm humidified air and sterilizing autoclave environment. Using a particle counter, post and pre-autoclave tests demonstrate significant micron particle reduction after autoclaving (fig. S3).

The needle valve utilizes change in flow momentum, flow path geometry and orifice flow design concepts allowing easy control of flow rate vs pressure drop ratio (i.e. flow coefficient) compared to gate and ball valve concepts (more binary valve concepts). It operates with less total pressure drop over the flow control ranges than typical globe valve concepts. The threading allows for control over the flow rates and offers the clinician the ability to make fine adjustments to the flow within the range of control. We used a gasket-inspired design featuring an O-ring (E1000-212/AS568-212, O-Rings EPDM, FDA EPDM, Marco Rubber \& Plastics, Seabrook, New Hampshire, USA) seated between the needle and chamber to ensure airtightness, thus reducing the risk of aerosolizing the virus into the surrounding environment. Final features of FloRest (Fig. 2A) included sealing to the external environment using unthreaded upper needle shafts for smoother interfaces between cap O-ring and needle during operation of valve and a delayed start in needle threading to provide earlier range of flow control and to allow for safe operation of valve by preventing full occlusion of flow to patient by clinician.

The FloRest has advantages compared with commercial valves in terms of the controllability, biocompatibility, and sterilizability. The FloRest had similar range of control compared to commercial gate valves (\#P20034 PVC SCH 40 1²-in FNPT Ball Valve; G300 Lead 
medRxiv preprint doi: https://doi.org/10.1101/2020.09.16.20195230; this version posted September 22, 2020. The copyright holder for this preprint (which was not certified by peer review) is the author/funder, who has granted medRxiv a license to display the preprint in perpetuity.

It is made available under a CC-BY-NC-ND 4.0 International license .

224 Free Brass Gate Valve, American Valve, Greensboro, North Carolina, USA) (Fig. 2B). However,

225 the Vent-Lock FloRest provides more control options than commercial valves, characterized by

226 more points available for the clinician to choose from corresponding to different tidal volumes

227 delivered. Furthermore, FloRest is produced with biocompatible, nontoxic materials that can be

228 safely sterilized, as compared to commercial ball valves with untested biocompatibility and

229 unknown sterilization protocols. Vent-Lock FloRest can be produced at an estimated $\$ 3.50$ per

230 device in 3-hour 40 min print and process time via fused deposition modeling (FDM) (e3d,

231 BigBox3D Ltd, Oxfordshire, UK; Little Monster, Tevo 3D Electronic Technology Co. Ltd,

232 Zhanjiang, China) using PETG (PETG 3D Printer Filament, FilaMatrix, Virginia, USA). With

233 stereolithography (SLA; Form 2, Form 3, or Form 3B, Formlabs), it costs approximately $\$ 25$,

234 and 16 hours production time with a 50 micron build layer height resolution, using surgical guide

235 resin (Surgical Guide, Formlabs). We demonstrate that the FloRest is leak proof through air

236 volume testing (fig. S2).

\section{Vent-Lock 3DP Flow Restrictor (FloRest) control of tidal volumes and PEEP}

We tested the use of Vent-Lock FloRest in the Johns Hopkins Medicine Simulation

240 Center (JHMSC) to confirm the following: 1) Allowing volumes to be distributed evenly

241 between patients, 2) variable patient control of PEEP, 3) variable patient tidal volume control

242 and 4) changes in the variable patient breathing settings does not alter breathing dynamics to the

243 standard patient.

244 We tested the Vent-Lock multiplexing system using a 1+1 split patient circuit (Fig. 1).

245 We used one ventilator (Puritan Bennett 840 Ventilator System, Avante Health Solutions) to

246 ventilate two patients with different lung compliances of $20 \mathrm{cmH}_{2} \mathrm{O}$ and $50 \mathrm{cmH}_{2} \mathrm{O}$. We first

247 tested using a pressure control mode, with inspiratory pressures set at $25 \mathrm{cmH}_{2} \mathrm{O}$ (additional 
medRxiv preprint doi: https://doi.org/10.1101/2020.09.16.20195230; this version posted September 22, 2020. The copyright holder for this preprint (which was not certified by peer review) is the author/funder, who has granted medRxiv a license to display the preprint in perpetuity.

It is made available under a CC-BY-NC-ND 4.0 International license .

248 ventilator settings available in Table S2). The Vent-Lock FloRest allowed adjustment of tidal

249 volumes delivered to patients between $7-\frac{3}{4}$ turns to $9-\frac{7}{8}$ turns (fully closed), corresponding to

$25021.5 \%$ of tidal volume control range and 2-1/8 turning range control (Fig. 3A). It allowed control

251 of $85.7 \%$ of the total range of delivered tidal volumes (compared to initial variable patient tidal

252 volume) with negligible change in tidal volume delivery to the standard patient (range: $99.86 \%$

253 and $103.2 \%$ initial standard patient tidal volume, mean: $102.1 \% \pm 0.98 \%$ ). We note that the total

254 expiratory volume reported by the ventilator trends with tidal volume delivered to the variable

255 patient (Fig. 3A) and the peak inspiratory pressures (PIP) of the variable patient and ventilator

256 peak inspiratory volumes also correspondingly decrease with decreases in tidal volume (Fig.

$2573 \mathrm{~B}, \mathrm{C})$, while peak inspiratory volumes remain stable for the standard patient and peak end

258 expiratory volumes remain stable for both patients during these changes.

259 We repeated Vent-Lock 1+1 multiplexing patient circuit with the ventilator on volume

260 control mode to deliver a total of $2 \mathrm{~L}$ of volume, corresponding to approximately $600 \mathrm{~mL}$ of tidal

261 volume per patient (additional ventilator settings available in table S1). We note that turning of

262 FloRest on the variable patient resulted in decrease of both tidal volumes and PIP (Fig. 4A,B).

263 However, this was accompanied with an increase in tidal volume delivery and PIP to the

264 standard patient (Fig. 4A,B), with relatively stable ventilator reported average pressures (Vent

$265 \mathrm{P}_{\mathrm{avg}}$ ) and PEEP (Fig. 4B). Thus, unlike in pressure control mode where control of delivery to the

266 variable patient was independent of the standard patient, flow restriction in the volume control

267 mode resulted in the modification of the ratio of tidal volumes delivered (Fig. 4C,

268 standard/variable patient tidal volume ratios). 
(A)

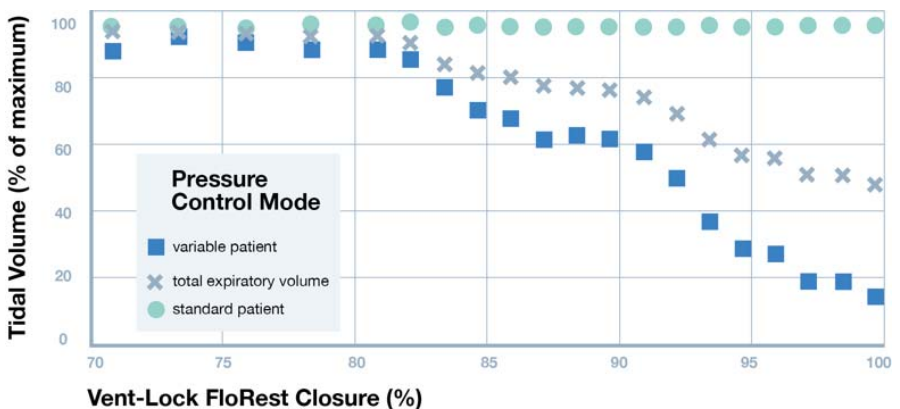

273 (B)

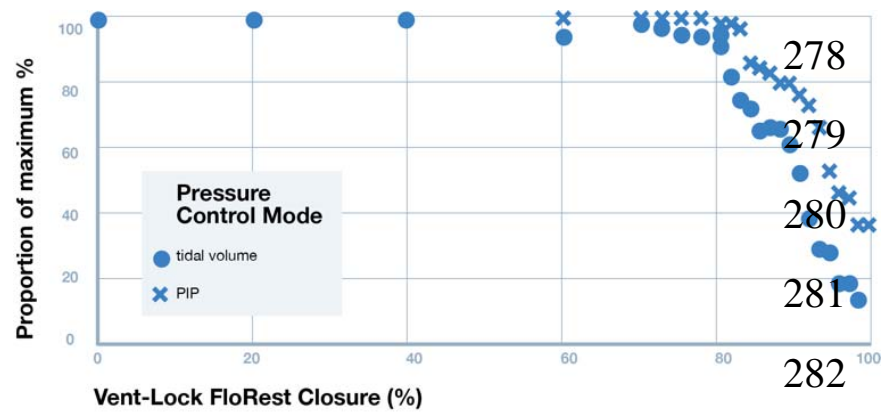

(C)

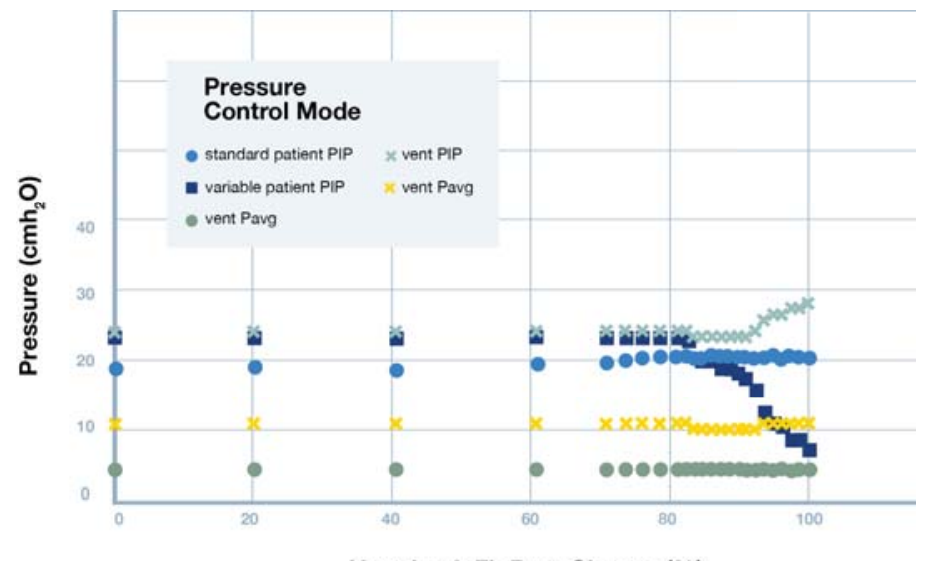

Vent-Lock FloRest Closure (\%)
Fig. 3. Pressure control mode: testing of VentLock ventilator multiplexor with a ventilator on pressure control mode ventilating two simulated patients with different lung compliances. (A) When used with a ventilator on pressure control,

283 Vent-Lock FloRest is capable of controlling tidal volumes delivered to the variable patient per turn, with no change 284 to tidal volumes delivered to the standard patient. (B) PIP of the standard patient remains stable, despite changing 285 PIP of the variable patient. Using a ventilator on pressure control, we determine the changes in standard and variable 286 patient breathing pressures with closure of the Vent-Lock FloRest, and the ventilator reported pressures. The positive inspiratory pressure (PIP) of the variable patient decreases with closure, while the standard patient PIP, and ventilator reported average breathing pressures $\left(\mathrm{P}_{\text {avg }}\right)$, and PEEP remain constant. We do note an increase in the ventilator reported PIP. (C) With the ventilator on pressure control, changes to tidal volume delivered to patients using Vent-Lock FloRest demonstrates a corresponding change in peak inspiratory pressures (PIP). 
(A)

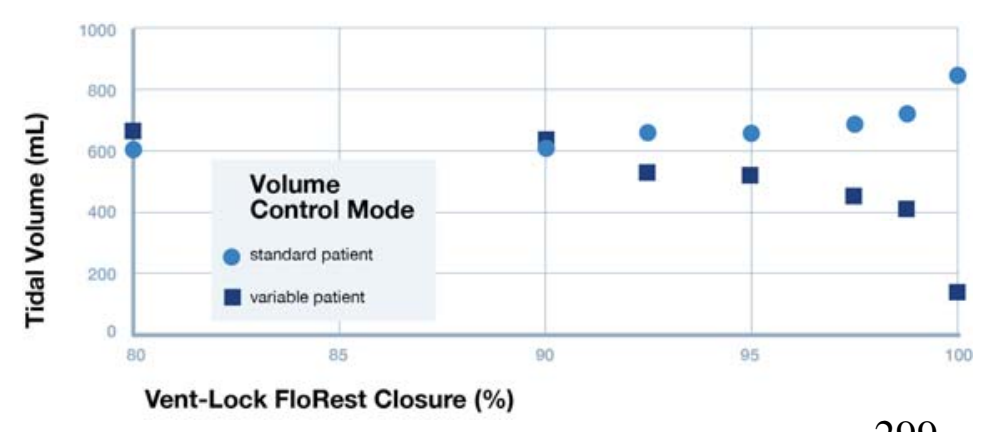

300

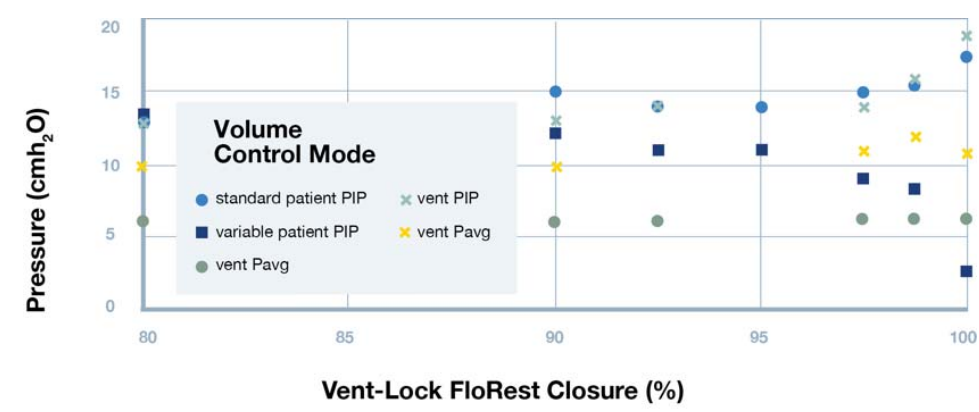

(B)

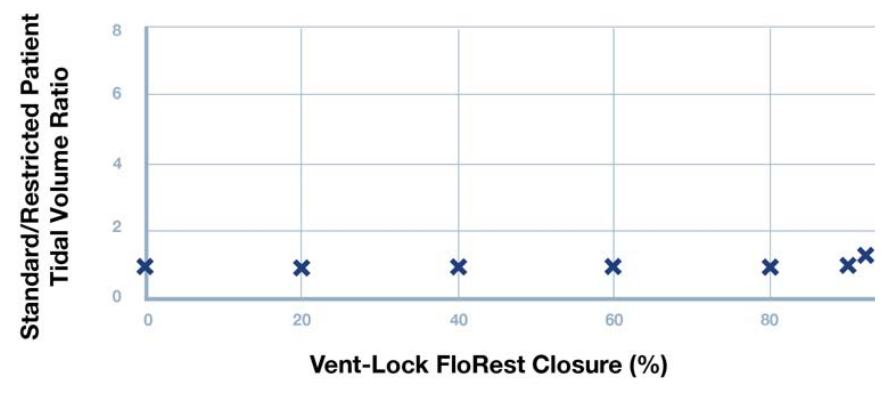

(D)

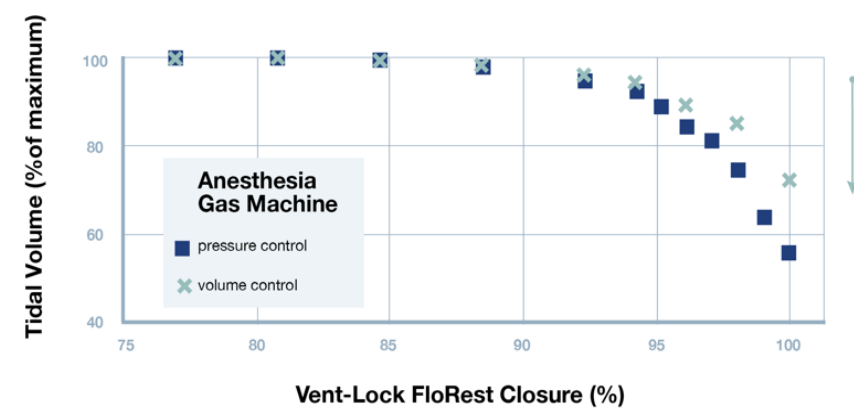

Figure 4. Volume control mode: testing of Vent-Lock ventilator multiplexer with a ventilator or anesthesia gas machine on volume control mode ventilating two simulated patients with different lung compliances. (A)

304 With the ventilator on volume control, decreases in variable patient tidal volumes result in increases in tidal volumes delivered to the standard patient. This indicates that in volume control mode, patient ventilation circuits are interdependent, and changes in one patient effects the other. (B) The ratios of the patient's tidal volumes (standard

307 patient/variable patient) per closure of the Vent-Lock FloRest with ventilators on volume control. (C) On ventilator

308 volume control and with Vent-Lock FloRest closure, the changes in peak inspiratory pressure (PIP) of the standard

309 patient and variable patient reflect that of tidal volume changes, while the ventilator reported PIP and $\mathrm{P}_{\text {avg }}$ increase,

310 and PEEP remains stable. (D)Vent-Lock FloRest was tested at Washington University in St. Louis using anesthesia

311 gas machines. The FloRest can be used to control delivered tidal volumes to the variable patient on both pressure

312 and volume control on anesthesia gas machines. 
medRxiv preprint doi: https://doi.org/10.1101/2020.09.16.20195230; this version posted September 22, 2020. The copyright holder for this preprint (which was not certified by peer review) is the author/funder, who has granted medRxiv a license to display the preprint in perpetuity.

It is made available under a CC-BY-NC-ND 4.0 International license .

314 We replicated results using anesthesia gas machines (North American Drager Narkomed

315 2a, Ardus Medical; GE Aestiva 5 7900, Datex Ohmeda) at an alternate test site (Washington

316 University in St. Louis, St. Louis, Missouri, USA). The 1+1 circuit was tested with the Vent-

317 Lock FloRest on the variable patient. On both pressure control and volume control settings, the

318 Vent-Lock FloRest demonstrated control of tidal volume delivered to the variable patient with

319 stable tidal volumes delivered to the standard patient. Pressure control allowed slightly greater

320 range of control (Fig. 4D, reduction of $43.9 \%$ tidal volume at close, compared to $27.5 \%$

321 reduction of tidal volume at close with volume control)

\section{Real-time pressure reporting with Vent-Lock manometer adaptors}

323 To facilitate continuous monitoring of pressures we designed a manometer adaptor that

324 allows clinicians to either spot-check pressures or continuously monitor with the use of standard,

325 disposable manometers such as those found on bag-valve-masks. The manometer adaptor can be

326 added in the circuit at any point and is designed to accurately reflect breathing pressures, such as

327 PIP and PEEP. We demonstrate that the manometer accurately reflects real-time pressures when

328 incorporated in the circuit (Fig. 5A). In a $1+1$ circuit with the ventilator on pressure control, the

329 PEEP setting was incrementally increased, and associated ventilator detected PEEPs and Vent-

330 Lock manometer reported pressures were recorded. The Vent-Lock manometer reported

331 pressures were equivalent to the PEEPs (Figure 5B). We also conducted blind tests, where one

332 researcher set the PEEP on the ventilator and a second researcher (blinded to ventilator PEEP

333 settings) reported PEEP as reported by the Vent-Lock manometer. The second researcher

334 consistently and accurately reported all test values between $0 \mathrm{cmH}_{2} \mathrm{O}$ to $50 \mathrm{cmH}_{2} \mathrm{O}$, in $5 \mathrm{cmH}_{2} \mathrm{O}$

335 increments, with total ten trials with no error. 
medRxiv preprint doi: https://doi.org/10.1101/2020.09.16.20195230; this version posted September 22, 2020. The copyright holder for this preprint (which was not certified by peer review) is the author/funder, who has granted medRxiv a license to display the preprint in perpetuity.

It is made available under a CC-BY-NC-ND 4.0 International license .

336

337

338

339 (A)

340

341

342

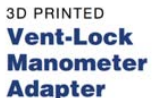

Adapter

(C)
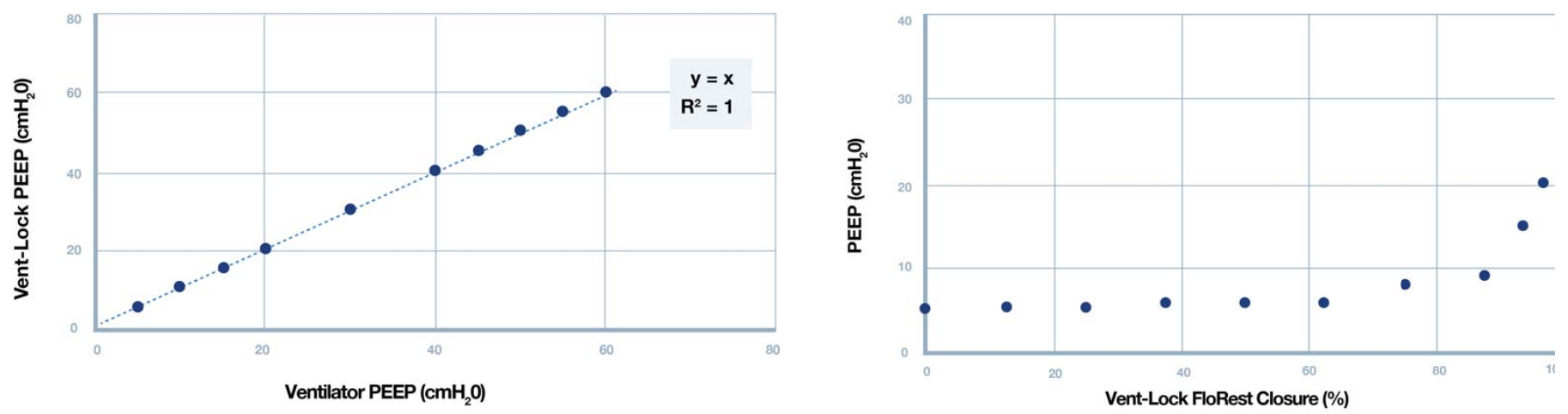

347 Fig. 5. Vent-Lock manometer adaptor. (A) The Vent-Lock manometer adaptor is incorporated in the split circuit,

348 and allows for the attachment of disposable manometers, thus provides accurate, real time readings of pressures. (B)

349 When placed on the expiratory limb, the Vent-Lock manometer adaptor accurately reflects PEEP as set by the 350 ventilator and as reported by the ventilator. (C) We use the Vent-Lock manometer to report the PEEP of the variable 351 patient, as adjusted by the Vent-Lock FloRest on the expiratory limb. With closure of the FloRest, the PEEP 352 increases. 
medRxiv preprint doi: https://doi.org/10.1101/2020.09.16.20195230; this version posted September 22, 2020. The copyright holder for this preprint (which was not certified by peer review) is the author/funder, who has granted medRxiv a license to display the preprint in perpetuity.

It is made available under a CC-BY-NC-ND 4.0 International license .

\section{Vent-Lock 3DP Flow Restrictor (FloRest) in Swine}

356 Two domestic swine were anesthetized and ventilated using the Vent-Lock system with constant

357 volume delivery. Swine were successfully ventilated for approximately four hours using a single

358 ventilator. Initial calculated dynamic lung compliances were 50.3 and $48.1 \mathrm{ml} / \mathrm{cm}_{2} \mathrm{O}$ for the

359 standard and variable swine, respectively. Throughout the experiment, minimum and maximum

360 dynamic compliance ranged from 50.3 to 244.5 and 37.9 to $87.1 \mathrm{ml} / \mathrm{cm} \mathrm{H}_{2} \mathrm{O}$ for the standard and

361 variable swine, respectively, reflecting the differences in tidal volumes those swine received

362 during the flow restriction trial. Serial ABGs were monitored (Fig. 6) and initial shared ventilator

363 settings were determined to be too high as both swine developed a respiratory alkalosis. At

364 approximately two hours this was corrected and $\mathrm{pH}$ and $\mathrm{paCO}_{2}$ were allowed to normalize for

365 one hour. Vent settings were not changed following this equilibration. Over the next hour the

366 Vent-Lock system was adjusted from fully open to fully closed, where air was still allowed to

367 pass even when Vent-Lock is closed to prevent unintentional hypoventilation. Respiratory

368 characteristics including tidal volume ratios, percent of total set tidal volume delivered,

369 inspiratory pressure and tidal volume are presented in Fig. 7. While the tidal volume delivered to

370 the variable swine decreased marginally, a substantial increase in tidal volume was noted to the

371 standard swine (Fig. 7D), similar to what is seen in simulation center testing with ventilator on

372 volume control mode. Arterial blood gas measurements demonstrated hyperoxia in both swine

373 (Fig. 7C). A hypercarbic respiratory acidosis occurred in the variable swine (Figure 6A, B) as the

374 Vent-Lock closure reached its final turn. Necropsy performed to assess for gross lung pathology

375 showed no significant findings of all lung lobes. 
(A)

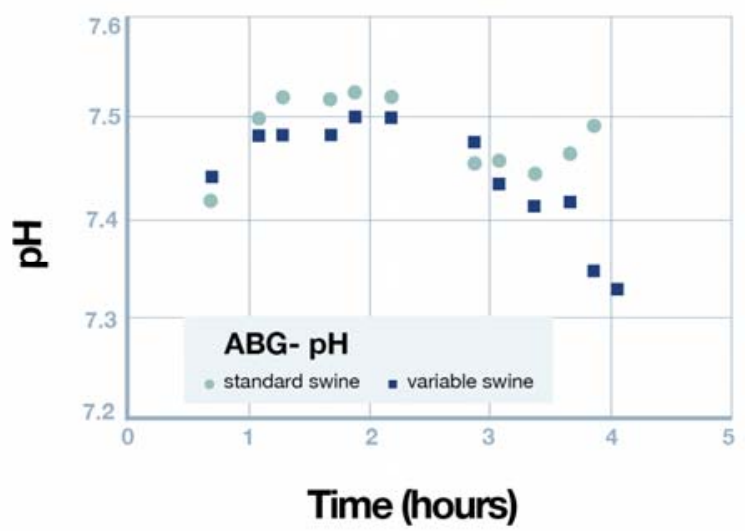

(C)

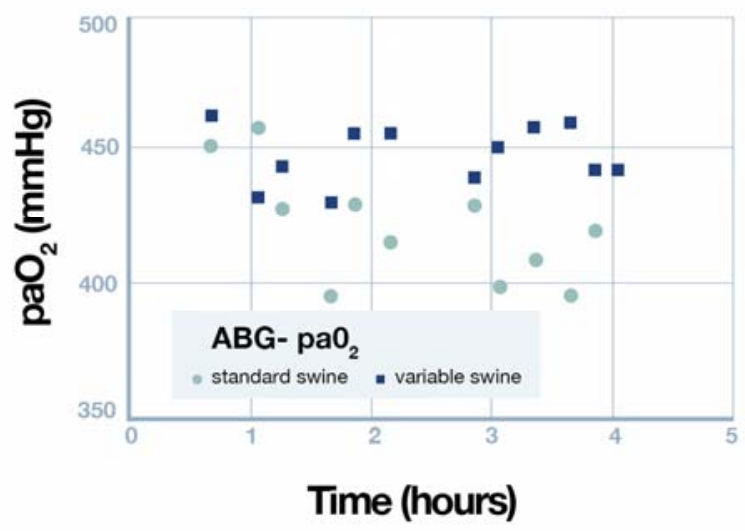

(B)

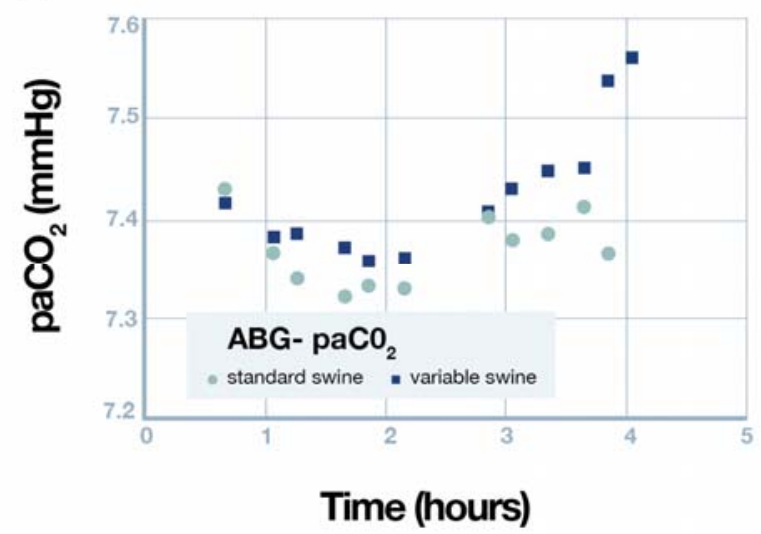

(D)

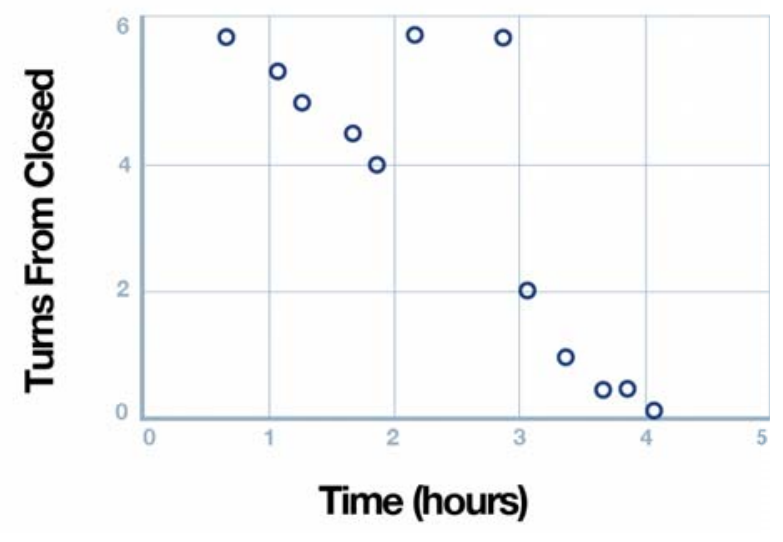

379 Fig. 6. Serial Arterial Blood Gases were monitored throughout the experiment. (A) $\mathrm{pH},(\mathrm{B}) \mathrm{paCO}_{2}$, and (C)

$380 \mathrm{paO}_{2}$ are all plotted as a function of time. (D) shows the number of turns from closed (with 6 turns being fully open)

381 as a function of the time of the experiment. Note that the Vent-Lock system was reopened at approximately 2 hours

382 due to development of hypercarbic alkalosis. 
(A)

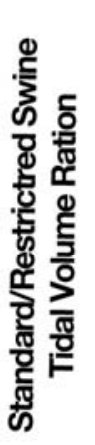

(C)

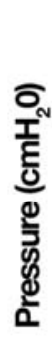

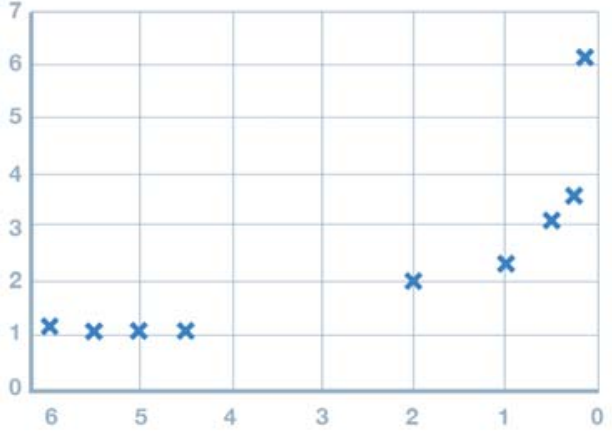

Vent-Lock Tums From Fully Closed
(B)

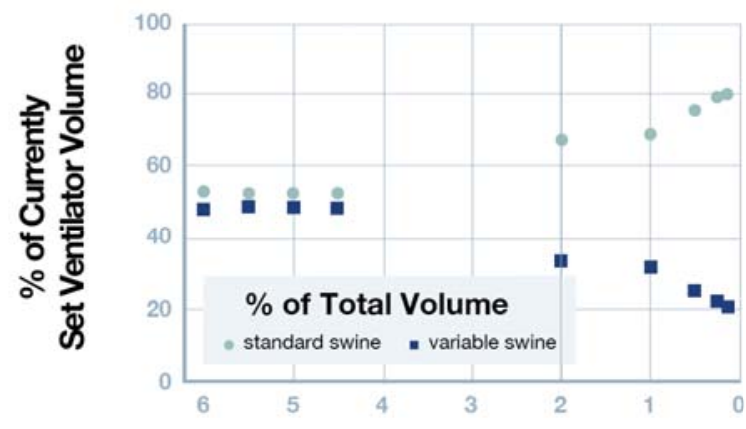

Vent-Lock Tums From Fully Closed

(D)

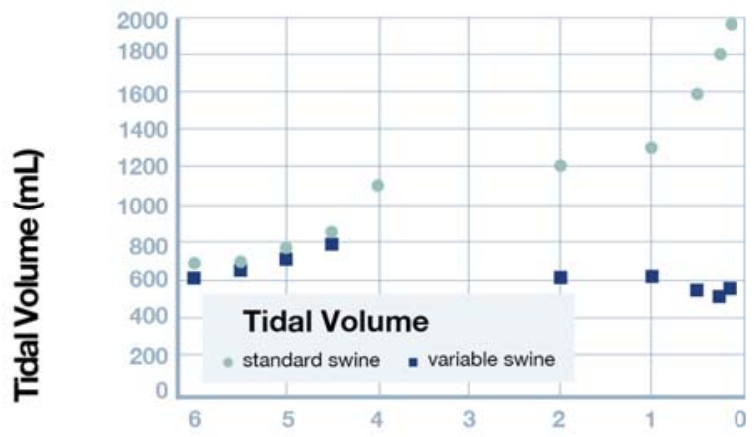

Vent-Lock Tums From Fully Closed

Vent-Lock Tums From Fully Closed

Fig. 7. Ventilatory parameters as a function of Vent-Lock aperture with 6 turns indicating fully open and zero fully closed. The lowest turn plotted is 0.25 turns from fully closed. (A) Ratio of tidal volumes between the standard and variable swine. (B) Percent of currently set ventilator tidal volume measured in each swine. (C) Peak inspiratory pressure measured in each swine. (D) tidal volume measured in each swine.

\section{DISCUSSION}

In the face of the COVID-19 pandemic, the importance of ventilators in the treatment of COVID-19 patients and the tenuous global supply of chain has resulted in the urgent need to increase ventilator capacity. One such solution to lack of ventilators is the ability to use one

393 ventilator to support multiple patients. Previously reported challenges include inability to 
medRxiv preprint doi: https://doi.org/10.1101/2020.09.16.20195230; this version posted September 22, 2020. The copyright holder for this preprint (which was not certified by peer review) is the author/funder, who has granted medRxiv a license to display the preprint in perpetuity.

It is made available under a CC-BY-NC-ND 4.0 International license .

394 independently control flow and pressure to each patient, development of a closed system to

395 prevent viral contamination, and continuous monitoring.

396 We used 3D-printing to rapidly prototype components of a ventilator splitter circuit that

397 allows one ventilator or anesthesia gas machine to ventilate two patients. The circuit addresses

398 aforementioned challenges and allows the clinician to control individual patient's pressures and

399 volumes, in a closed system with bacterial filters to reduce viral contamination. 3D printing was

400 selected as the prototyping and production modality due to rapid iterative production for research

401 and development and on-demand manufacturing to meet urgent needs in context of

402 biocompatible and sterilizable 3D printing materials. 3D printed components of the splitter

403 circuit were designed to include ventilator splitters, manometer adaptors for continuous pressure

404 monitoring and a flow restrictor to control tidal volumes and pressures.

405 The novel flow restrictor valve, Vent-Lock FloRest, is able to regulate tidal volumes to

406 one patient while maintaining flow to another patient (Fig. 3), and control PEEP when placed on

407 the expiratory limb with the manometer adaptor (Fig. 5). Design, research, and development was

408 driven by creating an airtight valve that allows precise control by the clinician. We demonstrated

409 that FloRest is compatible with multiple modes of ventilation strategies and anesthesia gas

410 machines (Fig. 4D). Vent-Lock FloRest has demonstrated volume and pressure control by

411 different physicians, using different mechanical ventilators or anesthesia gas machines, thus

412 demonstrating potential compatibility with different ventilators and anesthesia gas machines.

413 While the reproducibility of the Vent-Lock FloRest must be further investigated, this has

414 important global scalability implications as we demonstrate potential compatibility and

415 reproducibility not limited to make or type of ventilator or anesthesia gas machines, which may

416 be more commonly available in developing countries. 
medRxiv preprint doi: https://doi.org/10.1101/2020.09.16.20195230; this version posted September 22, 2020. The copyright holder for this preprint (which was not certified by peer review) is the author/funder, who has granted medRxiv a license to display the preprint in perpetuity.

It is made available under a CC-BY-NC-ND 4.0 International license .

Our studies reveal fundamental differences in tidal volume patterns with flow restriction

418 with the ventilator in volume versus pressure mode. In pressure control, Vent-Lock FloRest

419 allowed for reduction in delivered tidal volumes to the variable patient with stable volumes

420 delivered to the standard patient (Fig. 3A). However, in volume control, reduction in delivered

421 tidal volume to the variable patient resulted in a concomitant increase in tidal volume delivery to

422 the standard patient. This pattern is expected due to the continuous delivered volume maintained

423 by the machine; therefore, the Vent-Lock FloRest allowed regulation of the ratio, the

424 standard/variable patient tidal volume ratio (Fig. 4B). This ratio pattern of control is seen in both

425 ventilator volume control settings in the simulation center and replicated in vivo swine studies

426 using anesthesia gas machines (Fig. 5). The variation in both patients may be difficult for

427 clinicians to manage simultaneously. However, this ratio-based control delivered by Vent-Lock

428 FloRest can be critical for splitting legacy ventilators or anesthesia gas machines that may only

429 have volume control settings. One of the biggest challenges of splitting patients on ventilators is

430 that air will preferentially travel to the patient with the highest baseline lung compliance

431 resulting in unequal ventilation between the two patients. However, if Vent-Lock FloRest is

432 placed on the patient with the highest baseline lung compliance (variable patient), air flow can be

433 decreased, while simultaneously increasing air flow to the standard patient, until tidal volumes

434 are equilibrated between the two. Consequently, while we demonstrate that flow restriction

435 provides tidal volume control on ventilator pressure or volume control settings through different

436 mechanisms. We emphasize that especially during emergency use settings, providers appreciate

437 these differences in tidal volume control mechanisms, and select the setting most appropriate for 438 patients and practice settings. 
medRxiv preprint doi: https://doi.org/10.1101/2020.09.16.20195230; this version posted September 22, 2020. The copyright holder for this preprint (which was not certified by peer review) is the author/funder, who has granted medRxiv a license to display the preprint in perpetuity.

It is made available under a CC-BY-NC-ND 4.0 International license .

It is important to note that we validated ventilation multiplexing using anesthesia gas

440 machines. Anesthesia gas machines have ventilation functions, and are widely available globally,

441 even in developing countries. They are well suited to be repurposed for ICU ventilation in the

442 face of ventilator shortages, and considerations for modification and usage settings have been

443 addressed ${ }^{24}$. Our study provides follow up that in emergency situations, anesthesia gas machines

444 can potentially be multiplexed to ventilate multiple patients using the Vent-Lock 3DP circuit.

445 In companion with the Vent-Lock FloRest, we also produced a manometer adaptor (Fig.

446 5A) that can fit standardized disposable manometers commonly found in hospital settings, such

447 as the Ambu Disposable Pressure Monitor (Ambu, Copenhagen, Denmark). When the

448 manometer adaptor is placed in the Vent-Lock circuit, it allows for the continuous monitoring of

449 pressures. This is particularly important as the ventilator reported values may not accurately

450 reflect conditions of both patients and the rapidly changing states of both patients need to be

451 monitored with subsequent adjustments to pressures. We do note that while the manometer

452 adaptor with the manometer provides accurate readings (Fig. 5B), it is limited by the sensitivity

453 of the manometers for clinical use. Furthermore, using the manometer and adapter allows for real

454 time monitoring and facilitates individual control of PEEP with use of the Vent-Lock FloRest.

455 When the FloRest is placed on the expiratory loop of the patient, restriction of airflow results in

456 pressure increases between the patient and the FloRest, effectively functioning as PEEP (Fig.

457 5C), which can then be reported by the manometer and adapter. This PEEP change established

458 by FloRest and continuous monitoring does not affect the other patient split on the ventilator.

459 Therefore, this is a critical asset of the circuit that allows for more patient-tailored PEEP therapy

460 which is especially important in the treatment of patients with ARDS due to COVID-19 or other

461 lung pathologies. While most PEEP valves currently rely on a spring-loaded control system, this 
medRxiv preprint doi: https://doi.org/10.1101/2020.09.16.20195230; this version posted September 22, 2020. The copyright holder for this preprint (which was not certified by peer review) is the author/funder, who has granted medRxiv a license to display the preprint in perpetuity.

It is made available under a CC-BY-NC-ND 4.0 International license .

462 may be difficult to produce rapidly, especially via additive manufacturing. Our design

463 demonstrates control of expiratory pressures through flow restriction. However, we do note

464 challenges with FloRest in creating PEEP control, including that the PEEP was not changed until

465 near complete occlusion of the valve, at which point additional turns resulted in rapid changes in

466 PEEP (Fig. 5C). Consequently, we recognize that Vent-Lock FloRest requires further

467 optimization prior to clinical usage, but exists as a proof-of-concept that PEEP control may be

468 possible through a spring-less system.

469 Some limitations to our study include lack of human testing. While the swine in this

470 study had similar lung compliances which allowed us to show that the device was able to restrict

471 flow and that there is a finite tidal volume that is necessary and it is unknown how well this

472 reflects human physiology. In addition to urgent need, challenges in continuous monitoring must

473 be addressed prior to human studies. Future directions include developing a more rigorous

474 continuous monitoring of flow rates and delivered tidal volumes to patients to facilitate

475 adjustments of flow per FloRest. This is critical due to the dynamic lung physiologies of patients

476 with ARDS and preventing barotrauma or under or over ventilation. Therefore, we recommend

477 setting a target lung volume per patient, and monitoring via spirometry or airflow transducers,

478 such as the ones used in our swine studies (SS11LB airflow transducer (Biopac; Goleta, CA)).

479 Patient lung volumes and their oxygenation statuses should be spot checked with the spirometer

480 or transducers and arterial blood gases. Lastly, we emphasize that ventilator multiplexing is only

481 to be used in emergency situations after all alternatives have been exhausted. Despite our

482 findings of improved ventilator multiplexing functions with Vent-Lock and Vent-Lock FloRest,

483 additional studies are required to validate the safety and clinical considerations prior to 
medRxiv preprint doi: https://doi.org/10.1101/2020.09.16.20195230; this version posted September 22, 2020. The copyright holder for this preprint (which was not certified by peer review) is the author/funder, who has granted medRxiv a license to display the preprint in perpetuity.

It is made available under a CC-BY-NC-ND 4.0 International license .

484 translation to human subjects. However, as future pandemics and disasters may exhaust standard-

485 of-care for patient ventilation, Vent-Lock exists as a solution if "the other option is death" ${ }^{25}$.

486 During the COVID-19 pandemic, open sourcing has been used to expedite the creation of

487 vital personal protective equipment (PPE) by sharing files for the creation of masks, face shields

488 and ventilator adjuncts. Open sourcing and 3D printing have been proven to be helpful in the

489 developing world by providing low cost, easy to use medical products, low cost construction of

490 homes, water treatment devices and prosthetic limbs ${ }^{26}$. Thus, utilization of 3D printing to

491 produce Vent-Lock circuit and Vent-Lock FloRest allows for the rapid, on-demand, on-site

492 production to meet immediate needs. However, we recognize that our recommendation to use

493 specific medical grade materials that are easily sterilized can limit production in the developing

494 world. Further tests should be performed in varying material types to ensure accuracy in the

495 printing process and translation into actual use. While it is promising that our materials have

496 remained stable in humidified $40{ }^{\circ} \mathrm{C}$ for over 48 hours (fig. S3), we note that the material appears

497 more brittle after multiple autoclave cycles, and thus further testing is required to ascertain

498 stability across pressure gradients over weeks to months of use. Thus, we recommend single use

499 of the devices until further investigation.

500 Additionally, we do recognize that the value of Vent-Lock circuit is also in its ability to

501 be stored in preparation of emergency situations, such as disaster preparedness or in military

502 combat zones, where ventilator shortages can be expected. In this case, we believe that while 3D

503 printing production can meet initial interests, traditional manufacturing (such as injection

504 molding), may be a more cost-effective and time-efficient approach to fulfil demand. While

505 Vent-Lock circuit components are not currently optimized for traditional manufacturing, the

506 designs can easily be modified to allow for this production modality, while still maintaining 
medRxiv preprint doi: https://doi.org/10.1101/2020.09.16.20195230; this version posted September 22, 2020. The copyright holder for this preprint (which was not certified by peer review) is the author/funder, who has granted medRxiv a license to display the preprint in perpetuity.

It is made available under a CC-BY-NC-ND 4.0 International license .

access to 3D print for instances where manufacturing infrastructure is unavailable to produce this

508 device. Consequently, we believe that open sourced 3D printing methodology of Vent-Lock

509 production is appropriate for scalability in the face of urgent demand, such as the COVID-19

510 pandemic, but can also be transitioned into traditional manufacturing.

511 In this study, we developed Vent-Lock, a ventilator or anesthesia gas machine splitter

512 system with a flow restrictor (FloRest) that can modify flow rates per patient for patient tailored

513 therapies. We provide proof-of-concept that two swine can be safely split using one anesthesia

514 gas machine. While additional work is critical for the safe use of ventilator multiplexing, our

515 data supports the feasible use of ventilator splitting for emergency situations, such as in face of

516 COVID-19.

518 MATERIALS AND METHODS

\section{3D printing procedure.}

$5203 \mathrm{D}$ printing of the Vent-Lock splitters, flow regulators, and manometer adaptors were produced

521 via stereolithography (Form 2, Form 3, or Form 3B, Formlabs) at 50 um layer resolutions, using

522 surgical guide resin (Surgical Guide, Formlabs). Print files were generated by CAD drawings

523 (SolidWorks, Dassault Systèms) and converted into G-code using the printer's accompanying

524 software package (PreForm, Formlabs). Support structures were minimized through design and

525 generated using PreForm where needed. Components were oriented in such a way that crucial

526 surfaces such as threads or O-ring ledges were not impacted by support structures. Prints were

527 post-processed by washes (2 cycle with 15 min per cycle) in $>99.5 \%$ isopropyl alcohol (CAS

528 Number: 67-63-0, Sigma Aldrich), followed by air-drying at $22{ }^{\circ} \mathrm{C}$ for 30 minutes, and post-

529 cured for 30 minutes with heat $60{ }^{\circ} \mathrm{C}$ for the Form 2 printer and $70{ }^{\circ} \mathrm{C}$ for the Form $3 \mathrm{~B}$ printer at 
medRxiv preprint doi: https://doi.org/10.1101/2020.09.16.20195230; this version posted September 22, 2020. The copyright holder for this preprint (which was not certified by peer review) is the author/funder, who has granted medRxiv a license to display the preprint in perpetuity.

It is made available under a CC-BY-NC-ND 4.0 International license .

$530405 \mathrm{~nm}$ of light (Form Cure, Formlabs). O-rings (E1000-212/AS568-212, O-Rings EPDM, FDA

531 EPDM, Marco Rubber \& Plastics, Seabrook, New Hampshire, USA) were added for improved

532 sealing. Production via fused deposition modeling (FDM) (e3d, BigBox3D Ltd, Oxfordshire,

533 UK; Little Monster, Tevo 3D Electronic Technology Co. Ltd, Zhanjiang, China) used PETG

534 Filament (PETG 3D Printer Filament, FilaMatrix, Virginia, USA). Print settings were a $0.2 \mathrm{~mm}$

535 layer height with $30 \%$ infill, nozzle temperature of $250{ }^{\circ} \mathrm{C}$, and bed temperature of $70{ }^{\circ} \mathrm{C}$;

536 supports were generated from the build platform, with no interior supports.

537 Sterilization Testing.

538 3D-printed parts produced from surgical guide resin were sterilized by dry vacuum autoclave $(\mathrm{Sr}$

539 24C Adv-Plus ${ }^{\mathrm{TM}}$, Consolidated Sterilizer Systems, Boston, Massachusetts, USA), 3 cycles at

$540120.0{ }^{\circ} \mathrm{C}, 20$ minutes sterilization time and 20 minutes dry time. Then, they were soaked in

$541>99.5 \%$ isopropyl alcohol (CAS Number: 67-63-0, Sigma Aldrich) for 30 minutes, air-dried at

$54222{ }^{\circ} \mathrm{C}$ for 30 minutes, and placed in an oven at $40{ }^{\circ} \mathrm{C}$ in humidified air for 48 hours

543 (VO1824HPC, Lindberg/Blue M Vacuum Oven 127.4L, Thermo Scientific, Waltham, MA,

544 USA). Particle count analyses were conducted using a particle counter (SOLAIR 3100,

545 Lighthouse Worldwide Solutions), detecting sizes 0.3 to 10 microns, for 1-minute cycles, and

546 performed for parts pre-autoclave, post-autoclave and post IPA wash, and humidified warm air

547 exposure at $40{ }^{\circ} \mathrm{C}$.

548 Vent-Lock 1+n(1) circuit and components. Vent-Lock circuits were assembled as depicted in

549 Fig. 1. Vent-Lock 3DP splitters, flow regulator, and manometer adaptors were used. Commercial

550 components include manometer (Ambu Disposable Pressure Manometer, Ambu, Copenhagen,

551 Denmark), one-way valves (22F x 22M, REF 50245, Mallinckrodt Pharmaceuticals), disposable 
medRxiv preprint doi: https://doi.org/10.1101/2020.09.16.20195230; this version posted September 22, 2020. The copyright holder for this preprint (which was not certified by peer review) is the author/funder, who has granted medRxiv a license to display the preprint in perpetuity.

It is made available under a CC-BY-NC-ND 4.0 International license .

552 bacteria filters (BSF104, Vincent Medical), and ventilator tubing (SKU: 999027588, Hudson

553 Rci).

554 Simulation Center Testing. Vent-Lock 1+n(1) circuits were tested at the Johns Hopkins

555 Medicine Simulation Center (JHMSC). The ventilator (Puritan Bennett 840 Ventilator System,

556 Avante Health Solutions) was using pressure control mode of ventilation (Volume Ventilation

557 Plus $^{\mathrm{TM}}$, Avante Health Solutions) with additional settings detailed in fig. S4. Vent-Lock 1+1

558 circuit was tested using test lungs simulating healthy lungs with variable compliances (Standard

559 patient: $\mathrm{R}_{\mathrm{p}}=2 \mathrm{cmH}_{2} \mathrm{O} / \mathrm{L} / \mathrm{s}$, RespiTrainer Advance, QuickLung, IngMar Medical; Variable

560 patient: $\mathrm{R}_{\mathrm{p}}=50 \mathrm{cmH}_{2} \mathrm{O} / \mathrm{L} / \mathrm{s}$, ASL 5000, IngMar Medical). Intrapulmonary data for both patients

561 were collected; data included peak inspiratory pressures, tidal volumes, and peak end expiratory

562 pressures. Five total values of tidal volume per data set were collected and averaged.

563 Corresponding ventilator reported data was also recorded, including total expiratory volumes,

564 peak inspiratory pressures, mean inspiratory pressures, and peak end expiratory pressures. Flow

565 restrictors (\#P20034 PVC SCH 40 1²-in FNPT Ball Valve; G300 Lead Free Brass Gate Valve;

566 \#P60SCPVC12 Stop and Waste Valve, American Valve, Greensboro, North Carolina, USA;

567 Vent-Lock 3DP FloRest) were used to restrict the variable patient's inspiratory flow rate per the

$5681+n(1)$ circuit (Fig. 1). Valve handles were turned at smallest increments permissible to close the

569 valve and documented as \% closure. Corresponding intrapulmonary data and ventilator reported

570 values were collected per handle closure and standardized to values (volumes and pressures) of a

571 fully open valve (reported as proportion of maximum, \%).

572 In vitro studies were also conducted at the Washington University Simulation Center

573 using two Datex-Ohmeda Aestiva anesthesia machines. One machine was set to deliver pressure

574 control ventilation in a manner similar to that performed at Johns Hopkins. This machine was 
medRxiv preprint doi: https://doi.org/10.1101/2020.09.16.20195230; this version posted September 22, 2020. The copyright holder for this preprint (which was not certified by peer review) is the author/funder, who has granted medRxiv a license to display the preprint in perpetuity.

It is made available under a CC-BY-NC-ND 4.0 International license .

575 connected in parallel to a $2 \mathrm{~L}$ anesthesia bag reservoir and a second Datex-Ohmeda Aestiva

576 machine that was set to spontaneous ventilation. The second machine served as a flow and

577 volume sensor for the Vent-Lock $1+n(1)$ circuit.

578 In vivo swine studies. Experiments were performed in accordance with the Guide for the Care

579 and Use of Laboratory Animals and were approved by the Institutional Animal Care and Use

580 Committee of Washington University School of Medicine (St. Louis, MO). Domestic swine (Sus

581 scrofa domesticus) were purchased from Oak Hill Genetics (Ewing, IL). The swine were

582 females, $72 \mathrm{~kg}$ each, 5 months old, and were Landrace-cross swine. Swine were sedated with a

583 telazol, ketamine, xylazine cocktail and intubated with a 7.0 endotracheal tube. Anesthesia was

584 maintained with isoflurane. Femoral venous and arterial catheterization was performed. Standard

585 ASA monitoring was maintained throughout the experiment. Swine were ventilated using a

586 single ventilator (Drager Narkomed 2A) with two circuits in parallel in an $1+n(1)$ configuration

587 with cross-ventilation restricted by using one-way check valves. Ventilation was maintained with

588 volume control. One swine was not flow-regulated and thus considered the standard patient,

589 while the other had a Vent-Lock 3DP 4.0 connected in the inspiratory limb and thus considered

590 the variable patient. Flow was measured at each expiatory limb with a SS11LB airflow

591 transducer (Biopac; Goleta, CA). Flow data were collected at $2 \mathrm{kHz}$ using an MP36 data

592 acquisition unit and BSL 4.1.3 software (Biopac; Goleta, CA). The spirometry data was then

593 smoothed with a $0.25 \mathrm{sec}$ wide moving median filter after removal of instrument noise below

$5940.08 \mathrm{~L} / \mathrm{sec}$ (determined by histogram inspection). The smoothed data was then numerically

595 integrated to estimate respiratory tidal volume, and a first order numeric derivative was used to

596 calculate the instantaneous respiratory rate. The noise floor for the integrated volume was

597 determined by histogram inspection resulting in a threshold of $90 \mathrm{~mL}$. The anesthesia record and 
medRxiv preprint doi: https://doi.org/10.1101/2020.09.16.20195230; this version posted September 22, 2020. The copyright holder for this preprint (which was not certified by peer review) is the author/funder, who has granted medRxiv a license to display the preprint in perpetuity.

It is made available under a CC-BY-NC-ND 4.0 International license .

598 the spirometry results were then aligned using common timestamps. All breaths spontaneously

599 initiated by the swine (identified by respiratory rates more than $30 \%$ away from the ventilator set

600 point) were removed from analysis. The mean and standard deviation for each anesthesia record

601 entry were calculated for respiratory rate, tidal volume, minute ventilation, and lung compliance.

602 All of the described analysis was performed using a custom MATLAB script (MATLAB 2019b,

603 The MathWorks, Inc., Natick, MA)]. Arterial and venous blood gas data were collected 15

604 minutes following any changes to the Vent-Lock 3DP device. Following the procedure, swine

605 were euthanized with an overdose $(\sim 150 \mathrm{mg} / \mathrm{kg})$ of supersaturated potassium chloride IV while

606 under anesthesia. Necropsy was performed to assess for any gross lung pathology.

607

608 REFERENCES

609 1. Poston, J. T., Patel, B. K. \& Davis, A. M. Management of Critically Ill Adults With

610 COVID-19. JAMA 323, 1839-1841 (2020).

611 2. GlobalData. 880,000 global ventilator shortage can only be met by new simple design

612 requiring minimal operator training time, says GlobalData.

613 https://www.globaldata.com/880000-global-ventilator-shortage-can-only-be-met-by-new-

614 simple-design-requiring-minimal-operator-training-time-says-globaldata/ (2020).

615 3. Oshitani, H., Kamigaki, T. \& Suzuki, A. Major Issues and Challenges of Influenza

616 Pandemic Preparedness in Developing Countries. Emerg. Infect. Dis. J. 14, 875 (2008).

617 4. Murray, C. J., Lopez, A. D., Chin, B., Feehan, D. \& Hill, K. H. Estimation of potential

618 global pandemic influenza mortality on the basis of vital registry data from the 1918-20

619 pandemic: a quantitative analysis. Lancet 368, 2211-2218 (2006).

620 5. Maclean, R. \& Marks, S. 10 African Countries Have No Ventilators. That is only part of 
622 https://www.nytimes.com/2020/04/18/world/africa/africa-coronavirus-ventilators.html

$623 \quad(2020)$.

624 6. Bartsch, S. M. et al. The Potential Health Care Costs And Resource Use Associated With COVID-19 In The United States. Health Aff. 10.1377/hlthaff (2020) doi:10.1377/hlthaff.2020.00426.

627 7. Ranney, M. L., Griffeth, V. \& Jha, A. K. Critical supply shortages - The need for England Journal of Medicine (2020) doi:10.1056/NEJMp2006141.

630 8. Xu, S. \& Li, Y. Beware of the second wave of COVID-19. Lancet 395, 1321-1322 $631 \quad(2020)$.

632 9. SCCM Rapid Cycle 3 Response Summary. Society of Critical Care Medicine (2020).

633 10. Sebastian, D. GM to Make 30,000 Ventilators for National Stockpile in \$489 Million Contract. Wall Street Journal https://www.wsj.com/articles/gm-to-make-30-000ventilators-for-national-stockpile-in-489-million-contract-11586347203 (2020).

636 11. United States Resource Availability for COVID-19. The Society of Critical Care Medicine https://sccm.org/Blog/March-2020/United-States-Resource-Availability-for-COVID-19 (2020).

639 12. Mirchandani, P. Health Care Supply Chains: COVID-19 Challenges and Pressing Actions. $640 \quad$ Ann. Intern. Med. (2020).

641 13. Neyman, G. \& Irvin, C. B. A Single Ventilator for Multiple Simulated Patients to Meet Disaster Surge. Acad. Emerg. Med. 13, 1246-1249 (2006).

643 14. Menes, K., Tintinalli, J. \& Plaster, L. How One Las Vegas ED Saved Hundreds of Lives 
644

645

646

647 15. Chatburn, R. L., Branson, R. D. \& Hatipoğlu, U. Multiplex Ventilation: A Simulation-

After the Worst Mass Shooting in U.S. History. Emergency Physicians Monthly

https://epmonthly.com/article/not-heroes-wear-capes-one-las-vegas-ed-saved-hundredslives-worst-mass-shooting-u-s-history/ (2017).

based Study of Ventilating Two Patients with One Ventilator. Respir. Care

respcare.07882 (2020) doi:10.4187/respcare.07882.

16. Consensus Statement on Multiple Patients Per Ventilator. The Society of Critical Care Medicine https://www.sccm.org/Disaster/Joint-Statement-on-Multiple-Patients-PerVentilato (2020).

17. Srinivasan, S. et al. Individualized System for Augmenting Ventilator Efficacy (iSAVE): A Rapidly deployable system to expand ventilator capacity. bioRxiv 2020.03.28.012617 (2020) doi:10.1101/2020.03.28.012617.

18. Impact of the Global Medical Supply Chain on SNS Operations and Communications. Impact of the Global Medical Supply Chain on SNS Operations and Communications (2018). doi:10.17226/25149.

19. Boyson, S. A defining moment in our medical supply chain crisis. The Hill https://thehill.com/opinion/international/490963-a-defining-moment-in-our-medicalsupply-chain-crisis (2020).

20. Attaran, M. \& Attaran, M. 3D Printing Role in Filling the Critical Gap in the Medical Supply Chain during COVID-19 Pandemic. Am. J. Ind. Bus. Manag. 10, 988-1001 (2020).

21. Zadpoor, A. A. Design for additive bio-manufacturing: From patient-specific medical devices to rationally designed meta-biomaterials. International Journal of Molecular 
medRxiv preprint doi: https://doi.org/10.1101/2020.09.16.20195230; this version posted September 22, 2020. The copyright holder for this preprint (which was not certified by peer review) is the author/funder, who has granted medRxiv a license to display the preprint in perpetuity.

It is made available under a CC-BY-NC-ND 4.0 International license .

Sciences (2017) doi:10.3390/ijms18081607.

668 22. FDA. Technical Considerations for Additive Manufactured Devices Draft Guidance for Industry and Food and Drug Administration Staff. Clim. Chang. 2013 - Phys. Sci. Basis

23. Ishack, S. \& Lipner, S. R. Applications of 3D Printing Technology to Address COVID-19

24. APSF/ASA. APSF/ASA Guidance on Purposing Anesthesia Machines as ICU Ventilators. Am. Soc. Anesthesiol. (2020).

25. Rosenthal, B. M., Pinkowski, J. \& Goldstein, J. ‘The Other Option Is Death': New York https://www.nytimes.com/2020/03/26/health/coronavirus-ventilator-sharing.html (2020).

26. Ibrahim, A. M. S. et al. Three-dimensional Printing in Developing Countries. Plast.

$$
\text { Reconstr. Surg. - Glob. Open 3, (2015). }
$$

ACKNOWLEDGEMENTS We would like to thank the Johns Hopkins Medicine Simulation

682 Center Jordan Duval-Arnould, Julie Perretta, and Joe Dwyer for use of the simulation center; Dr.

683 Thao (Vicky) Nguyen, Dr. Joe Katz for their advice; Dr. Adam Sapirstein for their medical 684 expertise; Dr. Sarah Clever for her support; the Johns Hopkins Applied Physics Lab for guidance 685 and advice; Dr. Gerald Brandacher and Yi-nan Guo for use of their autoclave; Gregory Bova for 686 loan of his particle counter; and Dr. Arun Agrawal and Azra Horowitz for their advice on 687 ventilator splitting. The authors acknowledge financial support from the Johns Hopkins 688 University President's Response to COVID-19 Fund, the Start-Up Fund from the Whiting 689 School of Engineering at Johns Hopkins University, support from the Department of Civil and 
medRxiv preprint doi: https://doi.org/10.1101/2020.09.16.20195230; this version posted September 22, 2020. The copyright holder for this preprint (which was not certified by peer review) is the author/funder, who has granted medRxiv a license to display the preprint in perpetuity.

It is made available under a CC-BY-NC-ND 4.0 International license .

690 Systems Engineering and Johns Hopkins Center for Additive Manufacturing and Architected

691 Materials, and the National Science Foundation (DMREF-1628974). JU acknowledges financial

692 support from the U.S. Army Research Office (ARO) sponsored NDSEG Fellowship program and

693 AT acknowledges support by a NASA Space Technology Research Fellowship.

694

695 COMPETING INTERESTS Authors Xun, Shallal, Unger, Tao, Torres, Vladimirov, Frye, 696 Singhala, Horne, Yesantharao, Kim, Talcott, Montana, Winters, Frisella, Kushner, Guest, Kang, 697 and Caffrey have no relevant disclosures. Dr. Burke receives research funding from the 698 International Anesthesiology Research Society Mentored Research Award. Dr. Sacks receives 699 unrestricted research funding from ViOptix Inc., and is co-founder of LifeSprout Inc.

700

701 AUTHOR CONTRIBUTIONS HX, JKG, SHK, and JC conceived the research. HX, CS, JU,

702 RHT, AT, MV, JF, MS, BW, JKG, SHK, and JC contributed to engineering designs and 703 production. HX, CS, JU, RT, AT, MV, JF, MS, PY, BSK, BW, JKG, SHK, and JC contributed to 704 experimental design and testing in the JHMSC. BH and JF contributed to communications and 705 graphic design. BB, MM, MT, MF, BK, and JMS contributed to simulation center testing and 706 swine studies at Washington University in St. Louis. JKG, SHK, and JC supervised the research. 707 All authors contributed to the drafting and editing of this manuscript.

708

709 FIGURE LEGENDS

710 Fig. 1. Vent-Lock ventilator multiplexing $1+n(1)$ circuit and 3DP components. Our $1+n(1)$

711 circuit proposes having a standard patient with minimal features, thus are ventilated per

712 ventilator settings. Additional patients added to the circuit will be considered n(1), and will have 
medRxiv preprint doi: https://doi.org/10.1101/2020.09.16.20195230; this version posted September 22, 2020. The copyright holder for this preprint (which was not certified by peer review) is the author/funder, who has granted medRxiv a license to display the preprint in perpetuity.

It is made available under a CC-BY-NC-ND 4.0 International license .

713 variable flow and PEEP as controlled by circuit components. Please note that all patients,

714 regardless of standard or variable, have one-way (check) valves and filters.

715

716

717

718

719

720

721

722

723

724

725

726

727

728

729

730

731

732

733

734

735

Figure 2. Design and performance of 3DP Flow Restrictor (FloRest). (A) Vent-Lock 3DP

Flow Restrictor (FloRest) contains three components. The O-ring between the cap and full-

height threaded needle interface at the top of the chamber to maintain air-tight seals. Both ends

of Vent-Lock FloRest are male ISO fittings to ensure connection to ventilator tubing. (B) Testing

with a ventilator on pressure control using simulation lungs at varying compliances demonstrates

that Vent-Lock FloRest provides more control options than commercial ball valves and gate valves, characterized by more available data points corresponding with different tidal volumes delivered.

Fig. 3. Pressure control mode: testing of Vent-Lock ventilator multiplexor with a ventilator on pressure control mode ventilating two simulated patients with different lung compliances. (A) When used with a ventilator on pressure control, Vent-Lock FloRest is capable of controlling tidal volumes delivered to the variable patient per turn, with no change to tidal volumes delivered to the standard patient. (B) PIP of the standard patient remains stable, despite changing PIP of the variable patient. Using a ventilator on pressure control, we determine the changes in standard and variable patient breathing pressures with closure of the Vent-Lock FloRest, and the ventilator reported pressures. The positive inspiratory pressure (PIP) of the variable patient decreases with closure, while the standard patient PIP, and ventilator reported average breathing pressures $\left(\mathrm{P}_{\mathrm{avg}}\right)$, and PEEP remain constant. We do note an increase in the ventilator reported PIP. (C) With the ventilator on pressure control, changes to tidal volume 
medRxiv preprint doi: https://doi.org/10.1101/2020.09.16.20195230; this version posted September 22, 2020. The copyright holder for this preprint (which was not certified by peer review) is the author/funder, who has granted medRxiv a license to display the preprint in perpetuity.

It is made available under a CC-BY-NC-ND 4.0 International license .

736 delivered to patients using Vent-Lock FloRest demonstrates a corresponding change in peak

737 inspiratory pressures (PIP).

738

739 Figure 4. Volume control mode: testing of Vent-Lock ventilator multiplexer with a

740 ventilator or anesthesia gas machine on volume control mode ventilating two simulated

741 patients with different lung compliances. (A) With the ventilator on volume control, decreases

742 in variable patient tidal volumes result in increases in tidal volumes delivered to the standard

743 patient. This indicates that in volume control mode, patient ventilation circuits are

744 interdependent, and changes in one patient effects the other. (B) The ratios of the patient's tidal

745 volumes (standard patient/variable patient) per closure of the Vent-Lock FloRest with ventilators

746 on volume control. (C) On ventilator volume control and with Vent-Lock FloRest closure, the

747 changes in peak inspiratory pressure (PIP) of the standard patient and variable patient reflect that

748 of tidal volume changes, while the ventilator reported PIP and $\mathrm{P}_{\text {avg }}$ increase, and PEEP remains

749 stable. (D)Vent-Lock FloRest was tested at Washington University in St. Louis using anesthesia

750 gas machines. The FloRest can be used to control delivered tidal volumes to the variable patient

751 on both pressure and volume control on anesthesia gas machines.

752 Fig. 5. Vent-Lock manometer adaptor. (A) The Vent-Lock manometer adaptor is incorporated

753 in the split circuit, and allows for the attachment of disposable manometers, thus provides

754 accurate, real time readings of pressures. (B) When placed on the expiratory limb, the Vent-Lock

755 manometer adaptor accurately reflects PEEP as set by the ventilator and as reported by the

756 ventilator. (C) We use the Vent-Lock manometer to report the PEEP of the variable patient, as

757 adjusted by the Vent-Lock FloRest on the expiratory limb. With closure of the FloRest, the

758 PEEP increases. 
medRxiv preprint doi: https://doi.org/10.1101/2020.09.16.20195230; this version posted September 22, 2020. The copyright holder for this preprint (which was not certified by peer review) is the author/funder, who has granted medRxiv a license to display the preprint in perpetuity.

It is made available under a CC-BY-NC-ND 4.0 International license .

Fig. 6. Serial Arterial Blood Gases were monitored throughout the experiment. (A) pH, (B)

$760 \mathrm{paCO}_{2}$, and (C) $\mathrm{paO}_{2}$ are all plotted as a function of time. (D) shows the number of turns from

761 closed (with 6 turns being fully open) as a function of the time of the experiment. Note that the

762 Vent-Lock system was reopened at approximately 2 hours due to development of hypercarbic

763 alkalosis.

764 Fig. 7. Ventilatory parameters as a function of Vent-Lock aperture with 6 turns indicating

765 fully open and zero fully closed. The lowest turn plotted is 0.25 turns from fully closed. (A)

766 Ratio of tidal volumes between the standard and variable swine. (B) Percent of currently set

767 ventilator tidal volume measured in each swine. (C) Peak inspiratory pressure measured in each

768 swine. (D) tidal volume measured in each swine.

769 SUPPLEMENTARY MATERIALS

770 Fig. S1. De novo ventilator circuit components produced via 3D printing

771 Fig. S2. Air-tightness tests of the Vent-Lock FloRest.

772 Fig. S3. Design files for Vent-Lock splitters, needle valve, and manometer adaptor.

773 Fig. S4. Tests of tidal volume control with and without O-rings.

774 Fig. S5. Comparisons of Vent-Lock FloRest performances depending on materials.

775 Table S1. The biodurability and sterilization conditions.

776 Table S2. Ventilator settings on 840 Ventilator System, Nellcor Puritan Bennett.

777 Mov S1. Leaky bubble test demonstrates Vent-Lock FloRest is airtight

778 Data S1. STL print files of Vent-Lock splitter, FloRest, and manometer adaptor

779 Data S2. MATLAB code used to analyze swine data 
medRxiv preprint doi: https://doi.org/10.1101/2020.09.16.20195230; this version posted September 22, 2020. The copyright holder for this preprint (which was not certified by peer review) is the author/funder, who has granted medRxiv a license to display the preprint in perpetuity.

It is made available under a CC-BY-NC-ND 4.0 International license .

\section{1}

782

783

784

785

786

787

788 